\title{
High lichen species richness in Polylepis australis forest: new records from South America and Argentina
}

\author{
Juan Manuel Rodriguez ${ }^{*}$, Raúl Enrique Díaz Dominguez, Helmut Mayrhofer², \\ Alfredo Passo $^{3}$ \& Daniel Renison ${ }^{1}$
}

\author{
Article info \\ Received: 6 Aug. 2020 \\ Revision received: 17 Nov. 2020 \\ Accepted: 23 Nov. 2020 \\ Published: 29 Dec. 2020
}

Associate Editor

Alice Gerlach

\begin{abstract}
The Polylepis australis forests in Central Argentina support a great biodiversity in a relative small area. As a result of this study focusing on the diversity and ecology of the lichen communities of these forests, we present five new species for South America: Rinodina ficta, R. malcolmii, R. obscura, Usnea glabrata, Tetramelas triphragmioides and eight taxa new for Argentina: Calicium abietinum, Erioderma leylandii subsp. leylandii, Leptogium microstictum, Phaeophyscia endococcinodes, Rinodina dolichospora, $R$. intermedia, Usnea cirrosa and $U$. flavocardia. Unidentified Usnea species, similar to U. silesiaca, were also characterized and discussed.
\end{abstract}

Key words: Caliciaceae, Collemataceae, Córdoba, Pannariaceae, Parmeliaceae, Physciaceae, taxonomy.

\section{Introduction}

Forest and shrubland patches with canopies dominated by $\sim 28$ species of the genus Polylepis occupy the uppermost forested slopes of the high mountains of tropical and subtropical South America (Fjeldså \& Kessler 2004; Renison et al. 2018; Segovia et al. 2018). These Polylepis forests exhibit huge environmental differences with a latitudinal distribution of $4500 \mathrm{~km}$ from Venezuela to Central Argentina, elevation ranges from 900 to $5000 \mathrm{~m}$ above sea level and includes the world record for the highest elevation displaying tree growth, and a large range of precipitations from 100 to $3000 \mathrm{~mm}$ (Harden et al. 2013; Cuyckens et al. 2016; Renison et al. 2018). As a result of their isolation and a relatively stable climate throughout the Pleistocene, many Polylepis forests are inhabited by species of birds, rodents, plants and fungi with high levels of endemisms (Tarifa \& Yensen 2001; Calvelo \& Liberatore 2002; Fjeldsa 2002; Bellis et al. 2009; Robledo \& Renison 2010; Sylvester et al. 2017; Ames-Martínez et al. 2019; Quispe-Melgar et al. 2020). The ecology and

\footnotetext{
${ }^{1}$ Instituto de Investigaciones Biológicas y Tecnológicas, Centro de Ecología y Recursos Naturales Renovables. CONICET - Universidad Nacional de Córdoba. Av. Vélez Sarsfield 1610. CP 5000, Córdoba

${ }^{2}$ Institute of Biology, Division of Plant Sciences, NAWI Graz, University of Graz, Holteigasse 6, A-8010 Graz, Austria

${ }^{3}$ Instituto de Investigaciones en Biodiversidad y Medioambiente (CONICET - Universidad Nacional de Comahue). Quintral 1250, CP 8400, Bariloche, Río Negro

* Corresponding author e-mail: juan.rodriguez@unc.edu.ar
}

biodiversity of the heterogeneous forest types classified as 'Polylepis forests' are still poorly represented in the scientific literature with a recent review reporting 139 published studies, of which only 25 studies centered on Polylepis forest biodiversity (Renison et al. 2018).

Studies that report lichen diversity in Polylepis forests are particularly scarce. To the best of our knowledge, only two have been published. One in the context of edge effects in two Polylepis forest patches in the Andes of Colombia (Pulido Herrera \& Ramos Montaño 2016) and a second regarding the effects of fires in the mountains of Central Argentina (Perazzo \& Rodriguez 2019). Given the island nature of mountain highlands and the diversity of habitat types for Polylepis forests from arid regions to wet cloud forests, the lichen communities of the high mountain Polylepis forests of South America are largely unexplored and probably hide a wealth of new species to science.

According to the IUCN, 15 of the approximately 30 described Polylepis tree species are considered threatened. Hence, the forests they dominate including their endemic biota are also considered threatened (IUCN 2020). The reasons for their threatened status involve the limited distribution range of many of the Polylepis species in combination with an important human pressure on the forests. These forests are subjected to small scale, but continuous logging, burning to produce pastures for domestic livestock or land for agriculture, invasion by 
exotic species and are vulnerable to quick climate change (Fjeldså 2002; Fjeldså \& Kessler 2004; Cingolani et al. 2008; Renison et al. 2013; Cuyckens et al. 2016). The description of the Polylepis forests vanishing biodiversity has the potential to promote awareness from conservation agencies and local people about their rich endemic biota. In particular, to date no Polylepis forest endemic species for the most studied taxa such as birds, mammals and vascular plants have been described in the southernmost forest. However, new species to science and a host of possible endemics are emerging for wood decaying fungi and lichens in this location (Robledo et al. 2003; Rodriguez et al. 2011, 2017).

The southernmost Polylepis forests are dominated by $P$. australis and are located in the Higher Cordoba Mountain range of Central Argentina. These forest patches represent less than $10 \%$ of the vegetation cover in this location (Cingolani et al. 2008; Renison et al. 2013). Within the wooded patches, in addition to P. australis, as a secondary tree species Maytenus boaria may be found, as well as the shrub species Escalonia cordobensis and Berberis buxifolia and a large number herbaceous plants, ferns and grasses. The plant diversity along with climate gradient provide a wide variety of habitats ideal for the development of very diverse lichen communities. Recently, a review of the lichen genus Pannaria in Argentina included two new records in the $P$. australis forests (Passo et al. 2020) and the presence of one Oropogon species was rediscovered here (Rodríguez \& Filippini 2020). However, the lichen composition in P. australis forests is far from complete. The objective of this work is to describe noteworthy lichen species in Polylepis australis forests including new records for South America and Argentina.

\section{Material and methods}

Between the years 2015 and 2020 more than 1000 lichen collections were made in Polylepis australis forests from the mountains of Central Argentina ( $\left.31^{\circ} 34^{\prime} \mathrm{S}, 64^{\circ} 50^{\prime} \mathrm{W}\right)$. The elevation range is $1200-2800 \mathrm{~m}$ above sea level (Renison et al. 2002). Mean temperatures of the coldest and warmest months are $5.0^{\circ} \mathrm{C}$ and $11.4^{\circ} \mathrm{C}$, respectively, with no frost-free period. Mean annual precipitation is $920 \mathrm{~mm}$, with $83 \%$ of the rainfall being concentrated in the warmer months, between October and April (Colladon 2002; Renison et al. 2002). The vegetation in the mountains of Central Argentina consists of a mosaic of tussock grasslands, grazing lawns, degraded grazing lawns, eroded areas with exposed rock surfaces, granite outcrops, closed and open Polylepis australis forests or shrublands (Fig. 1). The lichen collection sites were in the Condorito National Park under permit DRC 321 (Argentinian National Parks Administration) issued to the first author.

The specimens were studied morphologically under stereomicroscope using standard techniques in lichenology. The anatomical characters were studied through handmade sections mounted in water or $\mathrm{KOH}$. The spore measurements are reported with their range. The percentage of cortex, medulla and axis in Usnea (\%CMA) is reported as $\min -\underline{X}-\max$ where ' $\min$ ' and ' $\max$ ' are the extreme observed values and $X$ the arithmetic mean. The lichen substances were identified by TLC (Orange et al. 2001) using A, B', C and/or G solvents. Also K (5\% $\mathrm{KOH}), \mathrm{C}$ (commercial bleach), $\mathrm{KC}$ ( $\mathrm{K}$ followed by $\mathrm{C}$ ), $\mathrm{PD}$ and UV (fluorescence at $366 \mathrm{~nm}$ ) were used when necessary (not needed for all species). For the specific morphological characters studied in each genus see the literature in the descriptions. All specimens are preserved in the CORD herbarium.

\section{Results and discussion}

Twenty-six lichenized fungi are presented in this work. Five species are new records for South America: Rinodina ficta, R. malcolmii, R. obscura, Usnea glabrata, and Tetramelas triphragmioides. Eight taxa are new records for Argentina: Calicium abietinum, Erioderma leylandii subsp. leylandii, Leptogium microstictum, Phaeophyscia endococcinodes, Rinodina dolichospora, $R$. intermedia, Usnea cirrosa and U. flavocardia. Twelve species are new records from central Argentina, all of them from Córdoba province: Amandinea punctata, Cratiria lauricassiae, Hypotrachyna sinuosa, $H$. vexans, Leptogium brebissonii, L. cyanescens, L. laceroides, L. phyllocarpum, Parmelinopsis swinscowii, Sticta fuliginosa, Usnea igniaria, U. subelegans. One species remains unidentified Usnea aff. silesiaca.

\section{New records for South America and Argentina}

Calicium abietinum Pers., Tentamen dispositionis methodicae Fungorum. Suppl. 59. 1798.

(Fig. 2A-C)

For a detailed description see Tibell (1996).

Diagnostic characters. Thallus immersed (Fig. 2A), brown-black stalked ascomata (0.2-0.45 mm long.) without pruina (Fig. 2B); ascospores 1-septate, brown and ellipsoid (Fig. 2A), ornamented when mature, (10-12 $\times$ 4.5-6.6 $\mu \mathrm{m})$.

Chemistry. $\mathrm{K}-$, $\mathrm{C}-$; there are no substances detected by TLC.

Notes. Calicium is a genus underestimated in Argentina: only C. glaucellum, C. hyperelloides, C. subcurtum and $C$. viride have been cited from Patagonia or to northeast of the country (Calvelo \& Liberatore 2002). In comparison with these species, C. abietinum is the only with the combination of an immersed thallus, brown to black stipitate and not pruinose apothecia.

Distribution and ecology. Calicium abietinum is a very common species in temperate regions (high mountains in tropical area). In South America, it is known from Paraguay and Venezuela (Tibell 1996). In P. australis forests, this species grows in well illuminated stands on deadwood.

Specimens examined. ARGENTINA. Córdoba. Los Gigantes, $2088 \mathrm{~m}, 31^{\circ} 24^{\prime} 17.0^{\prime \prime} \mathrm{S}, 64^{\circ} 48^{\prime} 29.4^{\prime \prime} \mathrm{W}$, on dead wood, 22 Sep. 
(A)
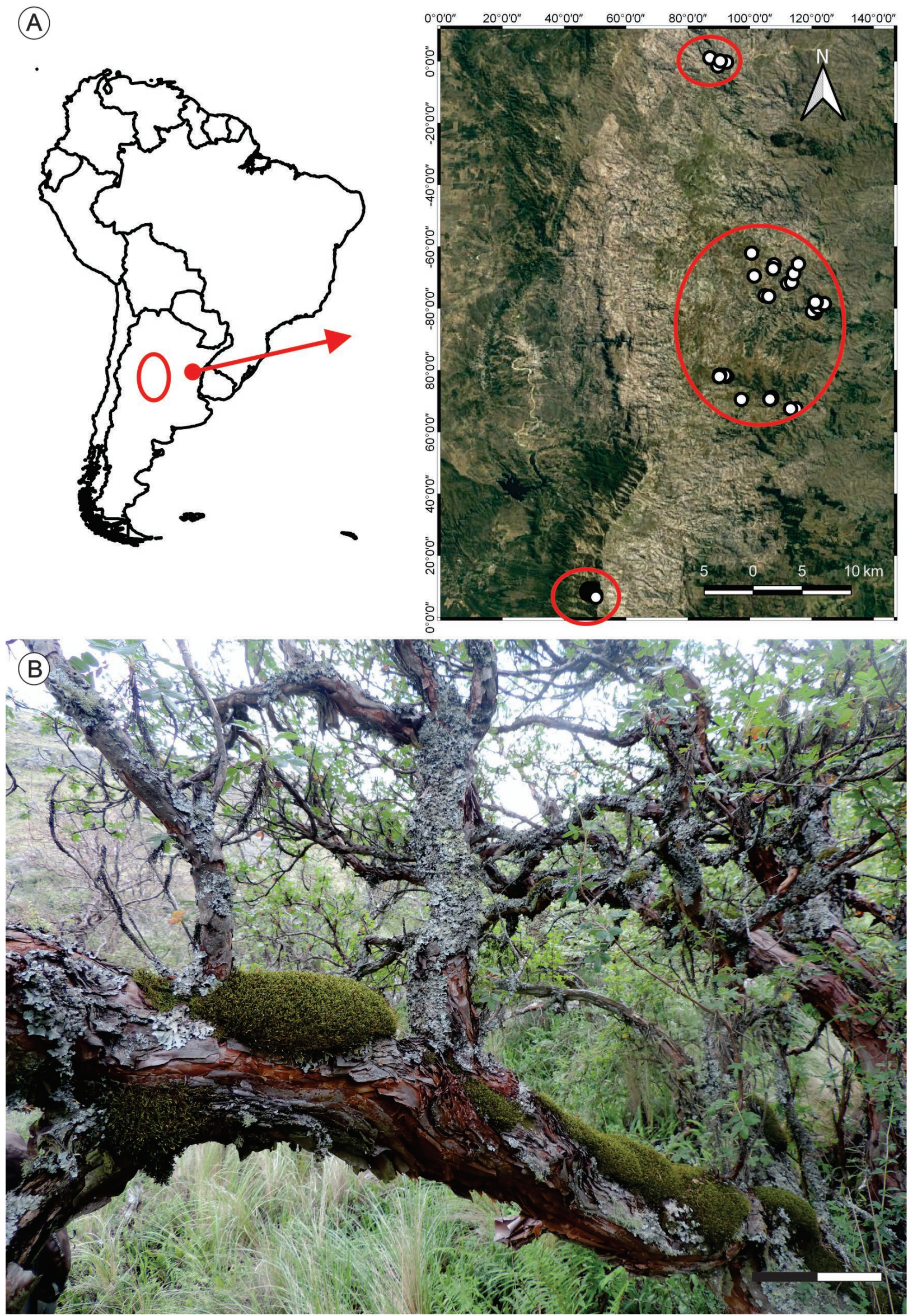

Figure 1. A. Location of the collection sites. B. Typical lichen communities in Polylepis australis forests. 
2018, Rodriguez 4674 (CORD). Parque Nacional Quebrada del Condorito, $2132 \mathrm{~m}, 31^{\circ} 44^{\prime} 26.5^{\prime \prime} \mathrm{S}, 64^{\circ} 48^{\prime} 24.3^{\prime \prime} \mathrm{W}$, on dead wood, 26 Dec. 2018, Rodriguez 4677 (CORD); ibid., 1827 m, $31^{\circ} 45^{\prime} 52.4^{\prime \prime} \mathrm{S}, 64^{\circ} 45^{\prime} 38^{\prime \prime} \mathrm{W}$, on dead wood, 29 Jan. 2019, Rodriguez 4690 (CORD).

Erioderma leylandii subsp. leylandii (Taylor) Müll. Arg., Flora 71: 24. 1888.

(Fig. 2D-E)

For a detailed description see Jørgensen \& Arvidsson (2002).

Diagnostic characters. Thallus foliose, more or less orbicular, grey to buff, shallowly incised (Fig. 2D); upper surface smooth to scabrid, glabrous centrally, otherwise covered with a soft arachnoid tomentum (Fig. 2E), with aggregated stiff hairs near the involute margins; lower surface whitish, mostly naked, with bundles of blackish rhizohyphae; apothecia marginal, disc brown, flat to convex, margin thin, finely hairy (Fig. 2E).

Chemistry. Medulla PD+ orange, $\mathrm{C}-$, $\mathrm{K}-$; TLC: pannarin.

Notes. This subspecies is similar to E. leylandii subsp. velligerum (Tuck) Jørg., cited for Patagonia in cold temperate Nothofagus ssp. forests, which is characterized by the presence of argopsin instead of pannarin, and a more conspicuously hirsute upper surface (Jørgensen 2001).

Distribution and ecology. In South America, Erioderma leylandii subsp. leylandii is a fairly common taxon in the central Andes, from Venezuela to Peru, and costal SE Brazil (Jørgensen \& Arvidsson 2002). It has been found growing on stone under the canopy.

Specimens examined. ARGENTINA. Córdoba. El Hueco, $1887 \mathrm{~m}, 31^{\circ} 58^{\prime} 17.1^{\prime \prime} \mathrm{S}, 64^{\circ} 56^{\prime} 48.1^{\prime \prime} \mathrm{W}$, on stone, 19 Oct. 2018, Rodriguez \& Díaz Dominguez 4678 (CORD).

Leptogium microstictum Vain., Dansk Botanisk Arkiv Udgivet af Dansk Botanisk Forening. Copenhagen 4: 18. 1926.

(Fig. 2F-H)

For a detailed description see Sierk (1964) and Kitaura (2012)

Diagnostic characters. Thallus foliose, loosely attached to substratum grey-bluish, thin, rather papery (Fig. 2F); lobes rounded, margins crisped; upper surface smooth to minutely bullate-foveolate (Fig. 2G); lower surface naked with a few hapters; apothecia small, up to $1.5 \mathrm{~mm}$, laminar, disc orange-brown, subpedicellate, flat, margin pale; ascospores fusiform, $18-25 \times 6-8 \mu \mathrm{m}, 3-6$ septated, with 1 or 2 transverse septum (Fig. $2 \mathrm{H}$ ).

Notes. This rare and poorly known species is characterized by its minute foveolae on the upper surface. It is similar to L. foveolatum Nyl. that has larger foveolae and spores (Kitaura 2012).

Distribution and ecology. It is the first record for the country and for southern South America, previously cited for USA, Mexico (Sierk 1964; Kitaura 2012), and Venezuela (Marcano et al. 1996). So far, it is only known from one specimen, growing among mosses on a shaded place.

Specimens examined. ARGENTINA. Córdoba, El Hueco, $1887 \mathrm{~m}, 31^{\circ} 58^{\prime} 17.1^{\prime \prime} \mathrm{S}, 64^{\circ} 56^{\prime} 48.1^{\prime \prime} \mathrm{W}$, on stone, 19 Oct. 2018, Rodriguez \& Díaz Dominguez 4691 (CORD).

Phaeophyscia endococcinodes (Poelt) Essl. Mycotaxon 7(2): 301. 1978.

For a detailed description see Moberg (1995).

Diagnostic characters. Thallus foliose, gray, without pruina (Fig. 2I); medulla orange-red (Fig. 2J); lower surface black, rhizines simple and black; apothecia frequent, 2-3 mm diam., sessile (Fig. 2K), margin concolorous with upper surface; ascospores ellipsoid, 20.3-27 × 8.5-2 $\mu \mathrm{m}$, of Pachysporaria-type (Fig. 2L).

Chemistry. Cortex K-, medulla K+ purple, TLC: skyrin.

Notes. This species is easily recognizable by the presence of orange-red pigment in the medulla.

Distribution and ecology. In South America the species is known from Brazil, Chile, Colombia, Peru and Venezuela (Moberg 1993; Sipman et al. 2008). Here, it has been found growing over bryophytes on stone.

Specimens examined. ARGENTINA. Córdoba. Parque Nacional Quebrada del Condorito, seccional Condorito, $1995 \mathrm{~m}$, $31^{\circ} 42^{\prime} 55.8^{\prime \prime} \mathrm{S}, 64^{\circ} 45^{\prime} 14.9^{\prime \prime} \mathrm{W}$, on bryophytes, 15 Dec. 2016, Rodriguez \& Perazzo 4646 (CORD).

Rinodina dolichospora Malme, Bihang till Kungliga svenska Vetenskaps-Akademiens Handlingar 28(1): 30. 1902.

(Fig. 3A-D)

For a detailed description see Mayrhofer et al. (1999).

Diagnostic characters. Thallus variable: crustose, thin and effuse, granulose (Fig. 3A) to thicker and areolate or phyllydiate (Fig. 3B); apothecia lecanorine, sessile and \pm frequent, thalline margin prominent, concolorous with the thallus, disc brown, epruinose, $0.75 \times 1.51 \mathrm{~mm}$ (Fig. 3C); ascospores Pachysporaria-type, 1-septate, brown, $22-31 \times 13-14.0 \mu \mathrm{m}$, frequently with minute granular or globular inclusions (Fig. 3D). There are no substances detected by TLC.

Notes. The type (Pachysporaria with granular inclusions) and size of spores separate Rinodina dolichospora from the other species of Rinodina from Polylepis forests studied in this contribution.

Distribution and ecology. The species has been described from Brazil (Malme 1902). It is also known from Australia (Mayrhofer et al. 1999), North America (Sheard 2010) and southern Europe (Giralt et al. 2009). In the forest stands of $P$. australis, this species is very common growing on trunks and twigs.

Selected specimens examined. ARGENTINA. Córdoba, Parque Nacional Quebrada del Condorito, 1894 m, 31 37'07.9"S, 64'43'16.8", on Polylepis australis, 21 Dec. 2018, Rodriguez 4670 (CORD). El Hueco, 1865 m, 31 ${ }^{\circ} 58^{\prime} 12.8^{\prime \prime} \mathrm{S}, 64^{\circ} 56^{\prime} 54.6^{\prime \prime}$, on Polylepis australis, 19 Oct. 2018, Rodriguez 4676 (CORD). 

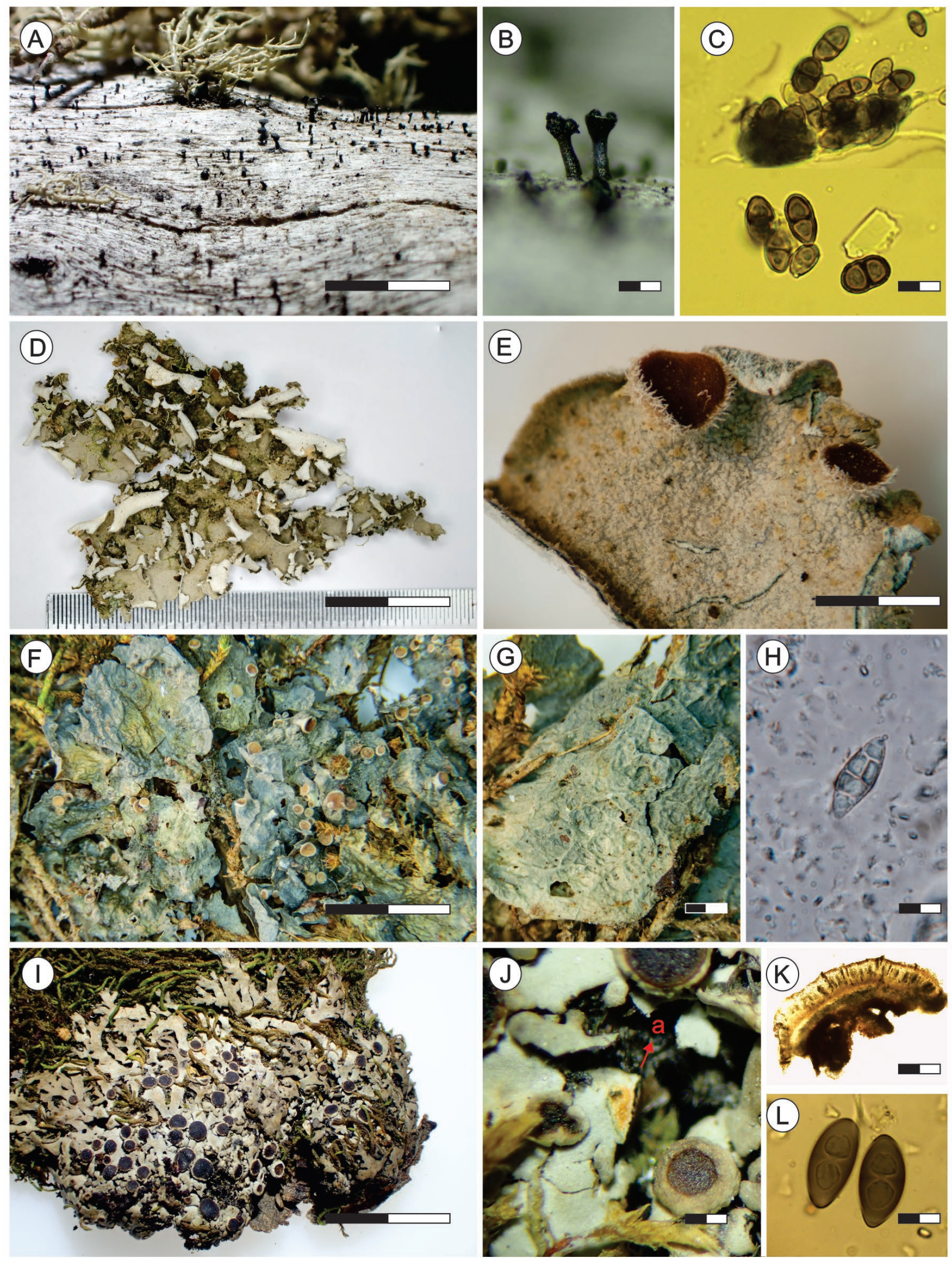

Figure 2. New records for Argentina. A-C. Calicium abietinum (Rodriguez 4674). A - thallus; B - stalked apothecia; C - 1-septate, brown and ellipsoid ascospores; D-E - Erioderma leylandii subsp. leylandii (Rodriguez \& Díaz Dominguez 4678); D - thallus; E - apothecia; F-H - Leptogium microstictum (Rodriguez \& Díaz Dominguez 4691); F - thallus; G - foveolae; H - 5-septated, fusiform ascospore with 1 transverse septum; I-L - Phaeophyscia endococcinodes (Rodriguez 4646); I - thallus; J - orange pigment in the medulla (letter a); $\mathrm{K}$ - apothecia; $\mathrm{L}$ - ascospores of Pachysporaria type. Scales: $A=3 \mathrm{~mm} ; \mathrm{B}=0.1 \mathrm{~mm} ; \mathrm{C}=11 \mu \mathrm{m} ; \mathrm{D}=1.5 \mathrm{~cm}, \mathrm{E}=2 \mathrm{~mm} ; \mathrm{F}=0.5 \mathrm{~cm} ; \mathrm{G}=2 \mathrm{~mm} ; \mathrm{H}=10 \mu \mathrm{m} ; \mathrm{I}=2.4 \mathrm{~cm}$; $\mathrm{J}=0.2 ; \mathrm{K}=48 \mu \mathrm{m} ; \mathrm{L}=10 \mu \mathrm{m}$. 

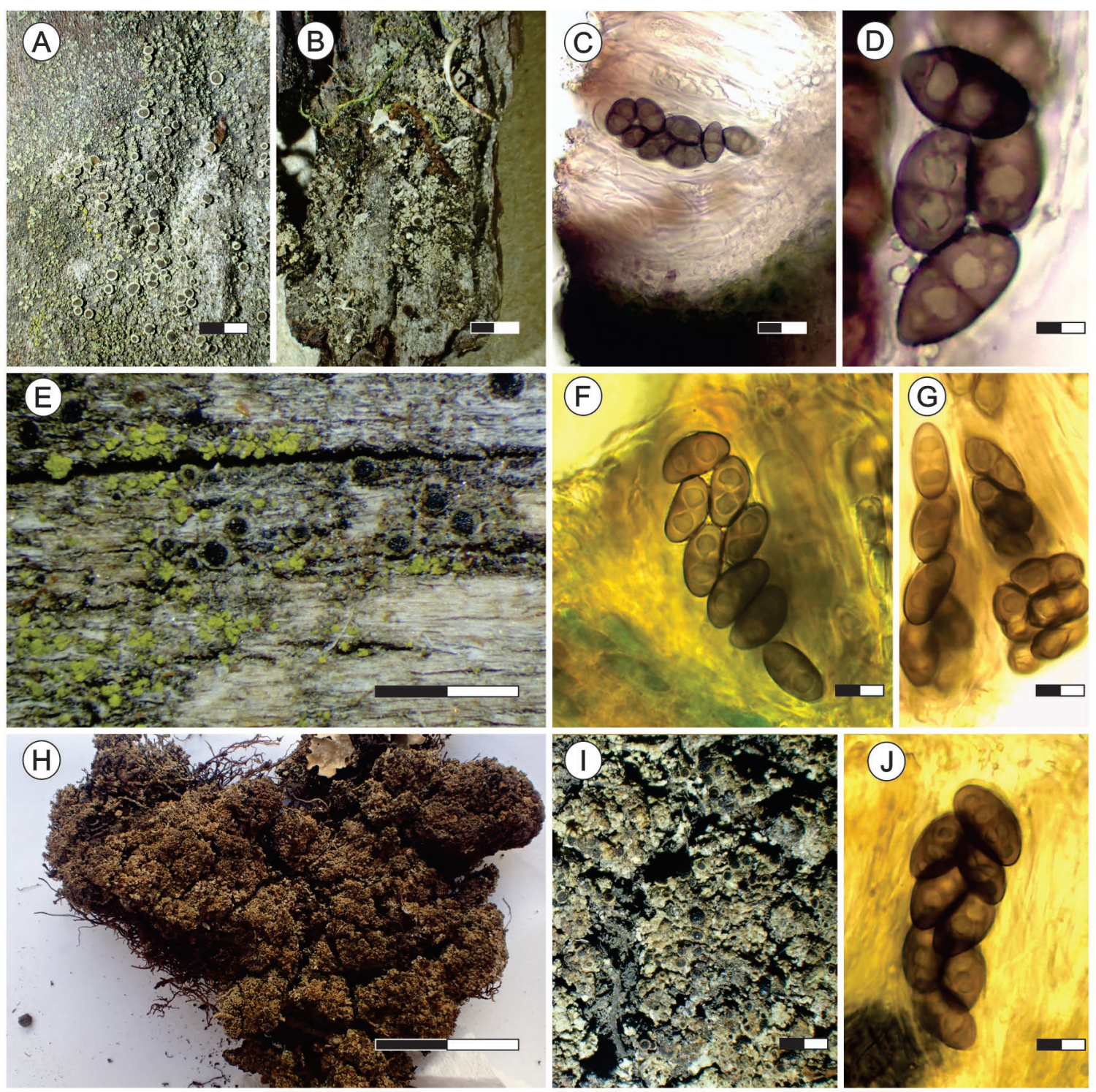

\section{Ka}
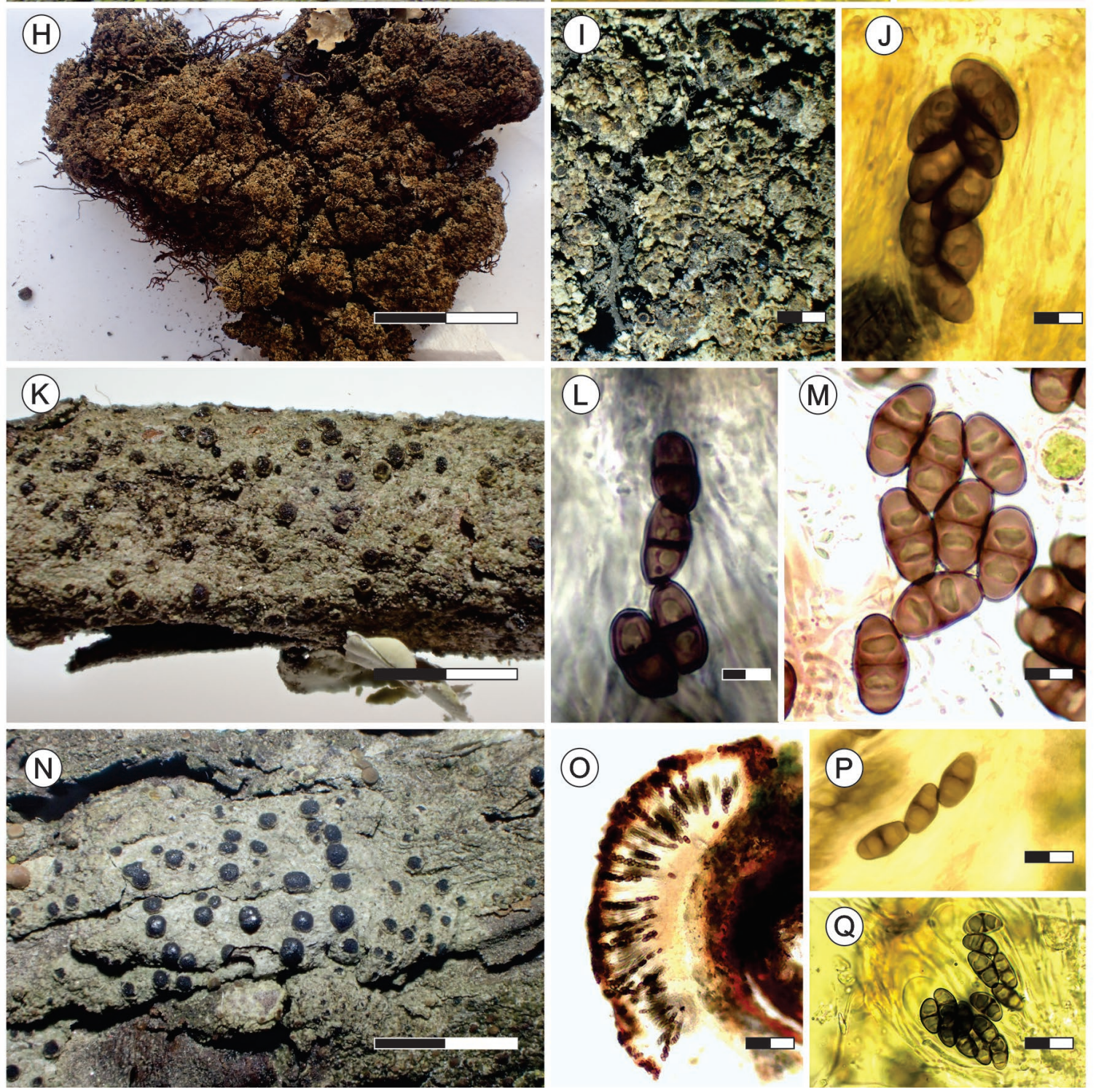
Rinodina ficta (Stizenb.) Zahlbr., Catalogus Lichenum Universalis 7: 518. 1931.

(Fig. 3E-G)

For a detailed description see Giralt \& Mayrhofer (1991) as R. boleana Giralt \& H. Mayrhofer.

Diagnostic characters. Thallus thin, crustose, inconspicuous, white to pale gray (Fig. 3E); apothecia lecanorine, sessile, $0.25-0.38 \mathrm{~mm}$ wide, thalline margin developed; disc plane, black, without pruina; ascospores Pachysporaria-type, ontogeny of type B (apical thickenings visible before the insertion of the septum), 11.2-14.7 $\times$ 6.1-7.2 $\mu \mathrm{m}$ (Fig. 3F-G). There are no substances detected by TLC.

Notes. This species is separated from the other Rinodina species studied here based on the very thin thallus, the smaller Pachysporaria-type spores and their ontogeny of type B.

Distribution and ecology. Rinodina ficta is new for South America. It is described from South Africa (Stizenberger 1890; Mayrhofer et al. 2014). It occurs also in New Zealand (Mayrhofer et al. 2007, as R. boleana) and Mediterranean Europe (Mayrhofer et al. 2014). It has been found on dead wood in well conserved Polylepis forest stands.

Specimen studied. ARGENTINA. Córdoba, Parque Nacional Quebrada del Condorito, $2132 \mathrm{~m}, 31^{\circ} 44^{\prime} 26.5^{\prime \prime} \mathrm{S}, 64^{\circ} 48^{\prime} 24.3^{\prime \prime} \mathrm{W}$, on dead wood, 26 Dec. 2018, Rodriguez 4677 (CORD).

Rinodina intermedia Bagl., Commentario della Società Crittogamologica Italiana 1(4): 315. 1863. (Fig. 3H-J)

For a detailed description see Mayrhofer et al. (2001)

Diagnostic characters. Thallus light-gray-green or ochraceous to light brown (Fig. $3 \mathrm{H}$ ), frequently with marginal lobes; apothecia sessile, broadly attached, frequent, often contiguous with dark brown to black disc (Fig. 3I); ascospores large, 20-31 × 12-15 $\mu \mathrm{m}$, submuriform with typically more than four locules at maturity (Fig. 3J).

Chemistry. K-, C-; TLC: deoxylichesterinic acid (Mayrhofer et al. 2001, Sheard 2010).

Distribution and ecology. Rinodina intermedia is widely distributed in dry regions at low altitudes; known from Colombia and Ecuador in South America, the Caribbean, western North America, Macaronesia, southern Europe, and north to the Channel Islands, U.K., eastwards to the Himalaya and as far south as Kenya and the Cape Verde Islands in Africa (Mayrhofer et al. 2001, Sheard 2010). It grows on soil or terricolous bryophytes, often in crevices between rocks, rarely on horizontal stems of dead shrubs
(Mayrhofer et al. 2001, Sheard 2010). In Polylepis forests, it grows on soil under the canopy.

Selected specimen examined. ARGENTINA. Córdoba. Los Gigantes, 31 ${ }^{\circ} 24^{\prime} 17.0^{\prime \prime} \mathrm{S}, 64^{\circ} 48^{\prime} 29.4^{\prime \prime} \mathrm{W}, 2088 \mathrm{~m}$, on soil, 22 Sep. 2018, Rodriguez 4665 (CORD).

Rinodina malcolmii Elix, Ch.Edler \& H.Mayrhofer, Australasian Lichenology 86: 96. 2020. (Fig. 3K-M)

For a detailed description see Elix et al. (2020).

Diagnostic characters. Thallus thin, continuous, crustose to verruculose, pale grey (Fig. $3 \mathrm{~K}$ ); apothecia frequent, lecanorine, adnate to sessile, $0.32-0.58 \mathrm{~mm}$ wide, thalline margin developed; disc plane to concave, brown to black, plane when mature; ascospores Pachysporaria-type when immature $(14-17.5 \times 7-9.2 \mu \mathrm{m})$ to Mischoblastia-type (Fig. 3M) when mature (17-21.6 $\times$ $8-9.5 \mu \mathrm{m})$. There are no substances detected by TLC.

Distribution and ecology. Rinodina malcolmii is new from South America. This species has been recently discovered (Elix et al. 2020) in New Zealand. Here it grows on P. australis bark and on twigs of Maytenus boaria or Berberis buxifolia mixed with many other crustose species (Lecanora spp., Caloplaca spp.) and small fruticose Ramalina and Usnea species.

Selected specimens studied. ARGENTINA. Córdoba, Los Gigantes, $31^{\circ} 23^{\prime} 45.1^{\prime \prime} \mathrm{S}, 64^{\circ} 49^{\prime} 78.0^{\prime \prime} \mathrm{W}, 1834 \mathrm{~m}$, on twigs of Polylepis australis, 09 Aug 2018, Rodriguez 4671 (CORD). El Hueco, 1880 m, 31 $58^{\prime} 19.7^{\prime \prime} \mathrm{S}, 64^{\circ} 56^{\prime} 59.1^{\prime \prime} \mathrm{W}$, on Polylepis australis, 19 Oct. 2018, Rodriguez 4672 (CORD).

Rinodina obscura Müll. Arg., Bulletin de l'Herbier Boissier 1: 40. 1893.

(Fig. 3N-Q)

For a detailed description see Mayrhofer et al. (1999).

Diagnostic characters. Thallus crustose thin, continuous, \pm rimose, pale grey to olive-grey (Fig. $3 \mathrm{~N}$ ); apothecia sessile, frequent, lecanorine at least when young, thalline margins poorly developed (Fig. 3O), thin or absent when mature; disc $0.3-0.7 \mathrm{~mm}$, brown to black, convex with age, epruinose; ascospores Physcia-type, 1-septate, brown, $12-15 \times 5.5-9 \mu \mathrm{m}$ (Fig. $3 \mathrm{P}-\mathrm{Q})$. There are no substances detected by TLC.

Distribution and ecology. Rinodina obscura is new from South America. It has been described in Australia (Müller 1893) and is widely distributed in southeastern mainland Australia and Tasmania (Mayrhofer et al. 1999). It is a rare species in $P$. australis forests.

Specimens examined. ARGENTINA. Córdoba, Los Gigantes, $1882 \mathrm{~m}, 31^{\circ} 24^{\prime} 01.9^{\prime \prime} \mathrm{S}, 64^{\circ} 47^{\prime} 56.1^{\prime \prime} \mathrm{W}$, on Polylepis australis, 21 Sep. 2018, Rodriguez 4666 (CORD). Parque Nacional

\footnotetext{
Figure 3. New Rinodina species for Argentina. A-D - Rinodina dolichospora (Rodriguez 4670); A - thallus granulose; B - thallus phyllidiate; $\mathrm{C}$ - detail of the hymenium; D - Pachysporaria type ascospores; E-G - Rinodina ficta (Rodriguez 4677); E - thallus; F - inmature ascospores in ascus; G - overmature ascospores; H-J - Rinodina intermedia (Rodriguez 4665); H - thallus; I - thallus and apothecia; J - submuriform ascospores in ascus; K-M - Rinodina malcolmii (Rodriguez 4671); K - thallus; L - overmature ascospores; M - ascospores of Mischoblastia type; N-Q - Rinodina obscura (Rodriguez 4679); N - thallus; O - hymenium; P - ascospores of Physcia type; Q - ascospores in ascus. Scales: $\mathrm{A}, \mathrm{B}=4 \mathrm{~mm} ; \mathrm{C}=20 \mu \mathrm{m} ; \mathrm{D}=6 \mu \mathrm{m} ; \mathrm{E}=2.1 \mathrm{~mm} ; \mathrm{F} \& \mathrm{G}=40 \mu \mathrm{m} ; \mathrm{H}=2.5 \mathrm{~cm} ; \mathrm{I}=2 \mathrm{~mm} ; \mathrm{J}=15 \mu \mathrm{m} . \mathrm{K}=2.1 \mathrm{~mm} ; \mathrm{L}=12 \mu \mathrm{m} ; \mathrm{M}=15 \mu \mathrm{m} ;$ $\mathrm{N}=5.6 \mathrm{~mm} ; \mathrm{O}=120 \mu \mathrm{m} ; \mathrm{P}=15 \mu \mathrm{m} ; \mathrm{Q}=16 \mu \mathrm{m}$.
} 
Quebrada del Condorito, $2127 \mathrm{~m}, 31^{\circ} 44^{\prime} 21.6^{\prime \prime} \mathrm{S}, 64^{\circ} 48^{\prime} 03.4^{\prime \prime} \mathrm{W}$, on Polylepis australis, 26 Dec. 2018, Rodriguez 4679 (CORD).

Usnea cirrosa Motyka, Lichenum Generis Usnea Studium Monographicum. Pars Systematica 2: 514. 1937.

(Fig. 4A-D)

For a detailed description and taxonomical notes see Clerc (2007) and Gerlach et al. (2017).

Diagnostic characters. Thallus shrubby, erect, up to $7 \mathrm{~cm}$ long, yellowish-grey (Fig. 4A); branches tapering, secondary branches constricted at ramification point (Fig. 4C), segments cylindrical to inflate, terete; papillae verrucose irregularly distributed, fibrils scarce to numerous; apothecia terminal and subterminal sometimes with red pigment in the margin (Fig. 4B); ascospores: ellipsoid $6.4-8.8 \times 3.2-6.4 \mu \mathrm{m}$; cortex thin and shiny $3.7-5,6-9.6 \%$; medulla moderately thick to thick $21-31-35 \%$ lax to dense; central axis thin to moderately thin, 17-26.5-41.5\% (Fig. 4D).

Chemistry. $\mathrm{K}+$ yellow turning orange to red, $\mathrm{C}-$-, $\mathrm{KC}-$; TLC: usnic and norstictic acids.

Distribution and ecology. Usnea cirrosa has been recorded from USA, Mexico, Colombia and Brazil (Gerlach et al. 2017). In Polylepis forests, it is a rare species.

Selected specimens examined. ARGENTINA. Córdoba, Parque Nacional Quebrada del Condorito, 1827 m, 31 ${ }^{\circ} 45^{\prime} 52.4^{\prime \prime} \mathrm{S}$, $64^{\circ} 45^{\prime} 38.0^{\prime \prime} \mathrm{W}$, on Polylepis australis, 29 Jan. 2019, Rodriguez \& Díaz Dominguez 4653 (CORD). Ibid., 2090 m, 31 44'25.5"S, 644ㄱ'56.3"W, 27 Dec. 2018, Rodriguez 4654 (CORD).

Usnea flavocardia Räsänen, Revista Universitaria (Santiago) 21: 139. 136.

(Fig. 4E-G)

For a detailed description see Clerc (2007) and Truong et al. (2011).

Diagnostic characters. Thallus shrubby, up to $5 \mathrm{~cm}$, yellowish-green frequently with red dots (Fig. 4E-F); branches tapering, secondary branches constricted at ramification point, segments cylindrical to inflated and terete; fibrils scarce, up to $3 \mathrm{~mm}$ long.; tubercles and papillae present; soralia circular to irregular, partially confluent, sometimes excavate; isidiomorphs present on immature soralia; cortex shiny, 4.1-5,9-8.2\%; medulla lax, white or with a yellow pigment around axis, 21.3-29.4-37.9\%; axis 16.1-29.4-43.6 (Fig. 4G).

Chemistry. Medula $\mathrm{K}+$ yellow turning orange. TLC: usnic and norstictic acids; $\mathrm{K}-$. TLC: usnic and psoromic acids. There are other chemotypes in this species (Truong et al. 2011), also in Argentina (unpubl. data). However, the specimens studied here belongs to the norstictic or psoromic acids chemotypes.
Distribution and ecology. Usnea flavocardia is known from North America, Europe, Macaronesia and North Africa (Clerc 2007) and South America (Truong et al. 2011). Usnea flavocardia grows on Maytenus boaria, Berberis buxifolia and $P$. australis mixed with $U$. cornuta, $U$. parvula thalli.

Selected specimens examined. ARGENTINA. Córdoba. Parque Nacional Quebrada del Condorito, seccional Condorito, 31 $44^{\prime} 42.6^{\prime \prime} \mathrm{S}, 64^{\circ} 46^{\prime} 49.7^{\prime \prime} \mathrm{W}, 2052 \mathrm{~m}$, on Polylepis australis, Oct. 2016, Rodriguez \& Perazzo 4647 (CORD). Ibid., $31^{\circ} 44^{\prime} 21.6^{\prime \prime} \mathrm{S}, 64^{\circ} 48^{\prime} 03.4^{\prime \prime} \mathrm{W}, 2127 \mathrm{~m}$, on Polylepis australis, 26 Dec. 2018, Rodriguez 4664 (CORD).

Usnea glabrata (Ach.) Vain., Annales Academiae Scientiarum Fennicae 6(7): 7. 1915.

(Fig. 4H-J)

For a detailed description see Clerc (2011).

Diagnostic characters: Thallus shrubby, erect to tufted, up to $3.5 \mathrm{~cm}$, greyish-green (Fig. $4 \mathrm{H}$ ); branches tapering to fusiform, secondary branches constricted at ramification point, segments inflated to cylindrical, terete; fibrils up to $2 \mathrm{~mm}$ mainly on the base; tubercles absent and papillae verrucose inconspicuous; soralia originated from the cortex ad initio, irregular to circular, plane, excavate to slightly convex, larger than the half of the branch, totally fusing toward terminal branches upturning the apices (Fig. 4I); soredia granular and isidiomorphs absent; cortex shiny, thin 4.1-6,3-10.2\%; medulla lax thick 16.3$27.8-34.3 \%$; axis thin, 20.3-31.8-47.0\% (Fig. 4J).

Chemistry. $\mathrm{K}+$ yellow turning red, TLC: usnic and salazinic acids; $\mathrm{K}-$, TLC: usnic acid.

Notes. The recently published $U$. subaranea and $U$. subglabrata (Truong \& Clerc 2016) are similar to U. glabrata. The former developed circular soralia that remain isolated, the cortex is rigid and the medullary hyphae arranged in bundles. The second species presents more conspicuous papillae and stictic acid in medulla. The characteristics observed fit well with the variation of U. glabrata described in Halonen et al. (1998), Herrera Campos et al. (2001) and Clerc (2007).

Distribution and ecology. Usnea glabrata is known from North America and Europe. This is the first record in South America. It grows on twigs of all of the woody plants present in the Polylepis forest. It is common to observe twigs fully covered with thalli of $U$. parvula, $U$. cornuta and U. glabrata together with Ramalina and Teloschistes species.

Selected specimen examined. ARGENTINA. Córdoba. Parque Nacional Quebrada del Condorito, seccional Condorito, $2058 \mathrm{~m} 31^{\circ} 44^{\prime} 40.8^{\prime \prime} \mathrm{S}, 64^{\circ} 46^{\prime} 41.8^{\prime \prime} \mathrm{W}$, on Polylepis australis, Oct. 2016, Rodriguez \& Perazzo 4692 (CORD).

Figure 4. New Usnea species for Argentina. A-D - Usnea cirrosa (Rodriguez 4653); A - thallus; B - reddish apothecia; C - secondary branches constricted at ramification point (letter a, arrow); D - longitudinal section; E-G - Usnea flavocardia (Rodriguez 4647); E - thallus; F - red dots on secondary branches; G - longitudinal section and slightly yellowish medulla; H-J - Usnea glabrata (Rodriguez \& Perazzo 4692); H - thallus; $\mathrm{I}$ - detail of soralia on terminal branches; J - longitudinal section; K-N - Usnea aff. silesiaca (Rodriguez 4683); K - thallus; L - black and annulated base; $\mathrm{M}$ - detail of soralia on terminal branches; $\mathrm{N}$ - longitudinal section. Scales: $\mathrm{A}=2.5 \mathrm{~cm} ; \mathrm{B}=1 \mathrm{~mm} ; \mathrm{C}=1 \mathrm{~mm} ; \mathrm{D}=0.3 \mathrm{~mm}$; $\mathrm{E}=5 \mathrm{~cm} ; \mathrm{F}=1 \mathrm{~mm} ; \mathrm{G}=1.7 \mathrm{~mm} ; \mathrm{H}=3 \mathrm{~cm} ; \mathrm{I}=0.5 \mathrm{~mm} ; \mathrm{J}=0.1 \mathrm{~mm} ; \mathrm{K}=2.5 \mathrm{~cm} ; \mathrm{L}=1 \mathrm{~cm} ; \mathrm{M}=2 \mathrm{~mm} ; \mathrm{N}=3 \mathrm{~mm}$. 


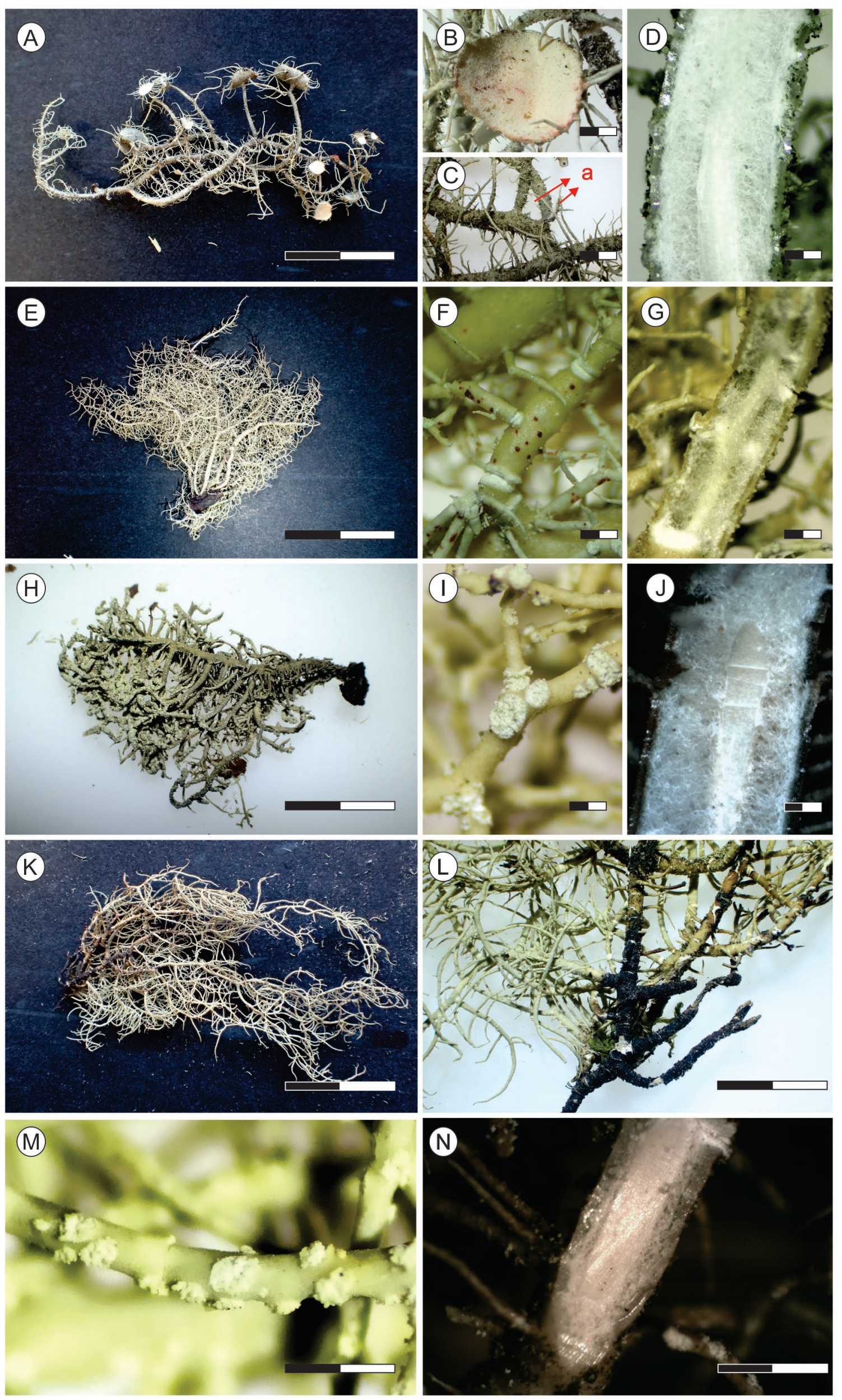


Usnea aff. silesiaca

(Fig. $4 \mathrm{~K}-\mathrm{N})$

Diagnostic characters. Thallus subpendulous to shrubby, up to $10 \mathrm{~cm}$ long, yellowish - green, sometimes slightly pruinose (Fig. 4K); ramifications anisotomic dichotomous; trunk and basal part of main branches jet black sometimes with reddish pigment, with numerous and conspicuous annular cracks extending upwards (Fig. 4L); branches cylindrical or tapering; secondary branches not narrowed at attachment points; segments cylindrical and terete in transverse section; papillae present, verrucous, mainly on main branches; fibrils slender, frequently in a fish-bone pattern, up to $5 \mathrm{~mm}$; soralia variable: initially punctiform then rounded to irregular, planar to concave, larger than half of the diameter of the branch, remaining discrete, sometimes confluent (Fig. 4M); isidiomorphs rare, generally absent on mature soralia; cortex matte to \pm glossy, thick 10.7-12.9-15.2\%; medulla white, compact to dense, very thin 4.4-12.3-16.2\%; axis thick 39.8-49.1-61.7\% (Fig. 4N).

Chemistry. K-, TLC: usnic acid.

Ecology. This species has been found growing on P. australis and rarely on M. boaria or fences.

Notes. Usnea aff. silesiaca is very similar to Usnea silesiaca (Clerc 1991, 2006, 2007) sharing the extended black pigment and anulate base, the CMA value and the morphology of branches and segments. Also the variation of soralia characteristics is in the range of $U$. silesiaca. However, the chemistry of Usnea aff. silesiaca without medullary compounds has not been observed previously in $U$. silesiaca and the medulla is compact to dense. Also there are specimens with a red tinge when the black pigmentation finishes in the first $\mathrm{mm}$ of main branches. For all these reasons, up to the moment, Usnea silesiaca cannot be confirmed in South America and more studies are needed to confirm the identity of Usnea aff. silesiaca. This species is similar to $U$. columbiana, a common subpendulous (to pendulous) species with an extended jet black base and thick cortex. However, U. columbiana possesses tuberculate soralia, tubercles and salazinic acid.

Selected specimens examined. ARGENTINA. Córdoba, Parque Nacional Quebrada del Condorito, 2064 m, 31 $42^{\prime} 59.3^{\prime \prime} \mathrm{S}$, $64^{\circ} 46^{\prime} 16.1^{\prime \prime} \mathrm{W}$, on Polylepis australis, 17 Sep. 2016, Rodriguez \& Perazzo 4683 (CORD). Ibid., $1791 \mathrm{~m}, 31^{\circ} 39^{\prime} 36.5^{\prime \prime} \mathrm{S}$, $64^{\circ} 42^{\prime} 11.0^{\prime \prime} \mathrm{W}$, on Polylepis australis, 21 Dec. 2018, Rodriguez 4684 (CORD).

Tetramelas triphragmioides (Anzi) A. Nordin \& Tibell, The Lichenologist 37(6): 497. 2005.

(Fig. 5A-C)

For a detailed description see Bungartz et al. (2007) as Buellia triphragmioides Anzi.

Diagnostic characters. Thallus crustose, continuous to granulose, pale yellow (Fig. 5A); apothecia frequent, lecideine, abundant, $0.2-1 \mathrm{~mm}$ in diam., sessile; disc black, sometimes slightly pruinose, flat to convex, margin conspicuous and excluded when mature; ascospores brown, 3-septate, ellipsoid to curved (Fig. 5B-C), 17.1-20.4 $\times$ 7.0-8.5 $\mu \mathrm{m}$.
Chemistry. $\mathrm{K}-, \mathrm{C}+$ orange, $\mathrm{UV}+$ orange; TLC: arthothelin.

Notes. This species is very notable because of the pale yellow color. Cratiria lauricassiae is another common buellioid species with triseptate spores in Polylepis forests. However, the thallus is green, $\mathrm{K}+$ yellow-orange, because of the presence of norstictic acid and UV-.

Distribution and ecology. Tetramelas triphragmioides is known from Europe, Asia and North America (Bungartz et al. 2007). This is the first mention in South America. It grows on wood of $P$. australis.

Selected specimens examined. ARGENTINA. Córdoba. Parque Nacional Quebrada del Condorito, seccional Condorito, $2020 \mathrm{~m}, 31^{\circ} 42^{\prime} 30.8^{\prime \prime} \mathrm{S}, 64^{\circ} 05^{\prime} 20.9^{\prime \prime} \mathrm{W}$, on Polylepis australis, 15 Feb. 2019, Rodriguez, Díaz Dominguez \& Estrabou 4641 (CORD). Ibid., $1841 \mathrm{~m}, 31^{\circ} 45^{\prime} 54.3^{\prime \prime} \mathrm{S}, 64^{\circ} 45^{\prime} 07.4^{\prime \prime} \mathrm{W}, 29$ Jan. 2019, Rodriguez 4673 (CORD).

\section{New records from central Argentina}

Amandinea punctata (Hoffm.) Coppins \& Scheid., The Lichenologist 25(4): 343. 1993.

(Fig. 5D-F)

For a detailed description see Bungartz et al. (2007) as Buellia punctata (Hoffm.) A.Massal.

Diagnostic characters. Thallus crustose, rimose, continuous, pale gray (Fig. 5D); apothecia frequent, lecideine, abundant, $0.2-0.4 \mathrm{~mm}$ in diam., sessile; disc black, flat to convex, margin soon excluded; ascospores brown, 1-septate, ellipsoid to slightly curved (Fig. 5E-F), 10.4-12.9 $\times 3.9-6.2 \mu \mathrm{m}$.

Chemistry. $\mathrm{K}-$, $\mathrm{C}-$; there are no substances detected by TLC.

Distribution and ecology. Amandinea punctata is a very common and widespread species (Bungartz et al. 2007). It has been cited for Argentina in Patagonia (Calvelo \& Liberatore 2002). In Polylepis forests, it is corticolous growing on trees, shrubs, fences or wood.

Selected specimen examined. ARGENTINA. Córdoba, Parque Nacional Quebrada del Condorito, 2090 m, 31 $44^{\prime} 25.5^{\prime \prime}$, 644ㄱ'56.3”W, 27 Dec. 2018, Rodriguez 4654 (CORD).

Cratiria lauricassiae (Fée) Marbach, Bibliotheca Lichenologica 74: 160. 2000.

(Fig. 5G-I).

For a detailed description see Nordin (2001) as Buellia lauricassiae (Fée) Müll. Arg.

Diagnostic characters. Thallus crustose, verruculose, continuous, greenish gray (Fig. 5G); apothecia frequent, lecideine, crowded in central part of the thallus, $0.2-0.4 \mathrm{~mm}$ in diam., sessile; disc black, flat, margin persistent; ascospores brown, 3-septate (Fig. 5H-I), $17.7-20.6 \times 5.8-8.9 \mu \mathrm{m}$.

Chemistry. $\mathrm{K}+$ yellow - red, C-; TLC: atranorin and norstictic acid (Nordin 2001). For differences with Tetramelas triphragmioides see under this species.

Distribution and ecology. Cratiria lauricassiae is a pantropical species occurring in Asia, Australia, North 

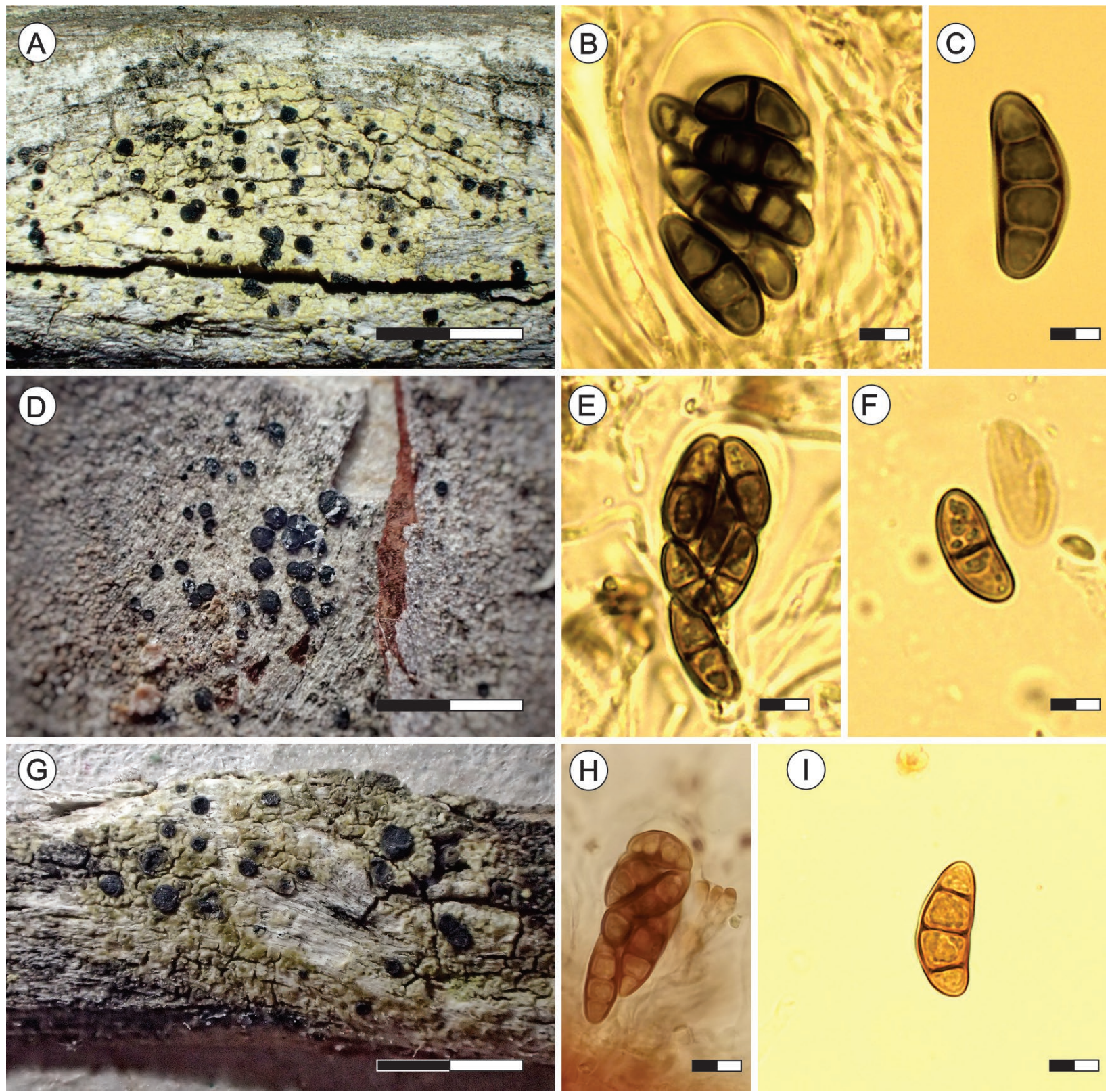

(1)

$(4)$

Figure 5. New crustose lichens for Argentina and Central Argentina. A-C - Tetramelas triphragmioides (Rodriguez, Díaz Dominguez \& Estrabou 4641); A - thallus; B - ascospores in ascus; C - 3-septate brown ascospore; D-F - Amandinea punctata (Rodriguez 4654); D - Thallus; E - ascospores in ascus; F - 1-septate brown ascospore; G-I - Cratiria lauricassiae (Rodriguez 4090, 4094); G - thallus; H - ascospores in ascus; I3-septate brown ascospore. Scales: $A=10 \mathrm{~mm} ; \mathrm{B}=19 \mu \mathrm{m} ; \mathrm{C}=8 \mu \mathrm{m} ; \mathrm{D}=3.6 \mathrm{~mm} ; \mathrm{E}=15 \mu \mathrm{m} ; \mathrm{F}=6.7 \mu \mathrm{m} ; \mathrm{G}=1.5 \mathrm{~mm} ; \mathrm{H}=15 \mu \mathrm{m}, \mathrm{I}=8 \mu \mathrm{m}$.

and South America (Nordin 1999; Cáceres 2007; Elix 2011). It has been cited for the Northeast of Argentina as Buellia lauricassiae by Osorio \& Ferraro (1975). To the best of our knowledge, this is the southernmost record for South America. This species has been collected on shrubs and trees of Polylepis and other woody plants.

Selected specimen examined. ARGENTINA. Córdoba, Parque Nacional Quebrada del Condorito, 2020 m, 31 ${ }^{\circ} 42^{\prime} 45.78^{\prime \prime} \mathrm{S}$, 644ㄴ $36.87^{\prime \prime} \mathrm{W}$, on shrubs, 15 Jan. 2017, Rodriguez 4090, 4094 (CORD).

Hypotrachyna sinuosa (Sm.) Hale, Smithsonian Contributions to Botany 25: 63. 1975.

(Fig. 6A-B)

For a detailed description see Adler \& Calvelo (2007).

Diagnostic characters. Thallus foliose, green yellowish, lobes eciliate (Fig. 6A); lower surface black, rhizines dense, dicotomous, black; soralia subterminal, capitate to orbicular (Fig. 6B); apothecia not seen.

Chemistry. Cortex $\mathrm{K}-$, medulla $\mathrm{K}+$ yellow to red; TLC: usnic, norstictic and salazinic acids.

Distribution and ecology. This species is widely distributed in the world mainly in temperate areas (Adler \& Calvelo 2007). In Argentina, it is common for Patagonia (Adler \& Calvelo 2007). Hypotrachyna sinuosa has been found growing on Polylepis and twigs of other shrubs.

Selected specimen examined. ARGENTINA. Córdoba, Parque Nacional Quebrada del Condorito, 1827 m, 31 ${ }^{\circ} 45^{\prime} 52.4^{\prime \prime} \mathrm{S}$, $64^{\circ} 45^{\prime} 38^{\prime \prime} \mathrm{W}$, on Polylepis australis, 29 Jan. 2019, Rodriguez 4689 (CORD). 

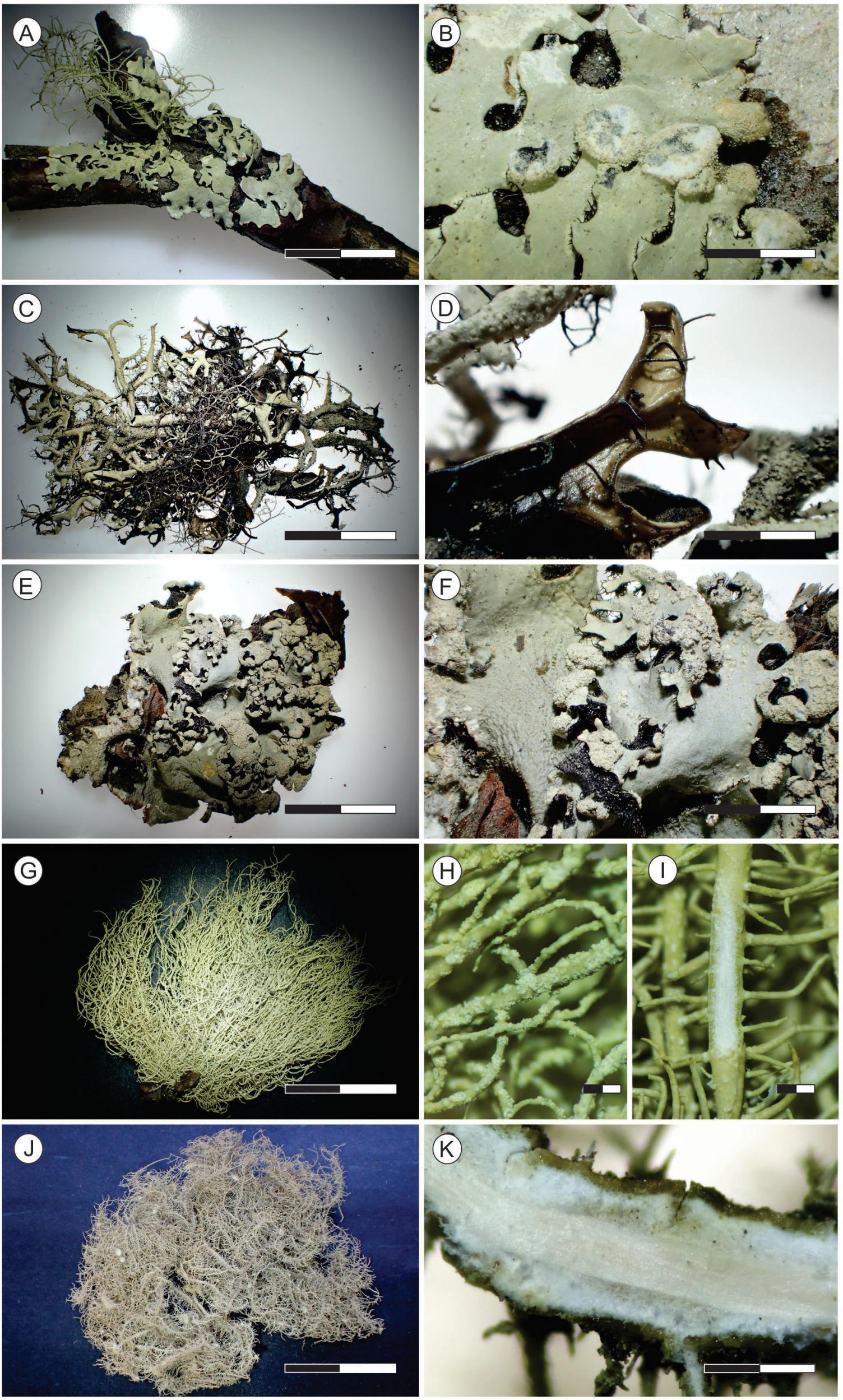
Hypotrachyna vexans (Zahlbr. ex W.L. Culb. \& C.F. Culb.) Divakar, A. Crespo, Sipman, Elix \& Lumbsch, in Divakar, Crespo, Núñez-Zapata, Flakus, Sipman, Elix \& Lumbsch, Phytotaxa 132(1): 33. 2013. (Fig. 6C-D)

For a detailed description see Calvelo \& Estrabou (1997) as Everniastrum vexans.

Diagnostic characters. Thallus foliose, lobes linear, up to $4 \mathrm{~cm}$ long., subdichotomously branched, up to $3 \mathrm{~mm}$ wide (Fig. 6C); underside black, brown to beige through the lobes apices (Fig. 6D); rhizines black, simple or branched, up to $2 \mathrm{~mm}$ isidia laminal, frequently branched, with an apical black cilia.

Chemistry. Cortex $\mathrm{K}+$ yellow, medula $\mathrm{K}+$ yellow - red, C-; TLC: atranorin and salazinic acid.

Notes. The presence of isidia and the type of rhizines separate Hypotrachyna vexans from $H$. americana, a very common species in Polylepis forests that possesses coacervate rhizines and no isidia or soredia (Calvelo \& Estrabou 1997).

Distribution and ecology. Hypotrachyna vexans has been recorded from Asia, North America and South America: Argentina, Brazil, Ecuador and Venezuela (Calvelo \& Estrabou 1997; Spielmann 2006). Previously, it has been recorded from northwest Argentina as Everniastrum vexans (Calvelo \& Estrabou 1997). It is rare in the Polylepis forest.

Specimen examined. ARGENTINA. Córdoba, Los Cajones, en parches de bosque, on Polylepis australis, 05 Jan. 2017, Rodriguez 4694 (CORD).

Leptogium brebissonii Mont., Histoire naturelle des Iles Canaries 3: 130. 1840.

(Fig. 7A-B)

For a detailed description see Galloway \& Jørgensen (1995)

Diagnostic characters. Thallus dark laden-green, lobate, thin and papery when dry (Fig. 7A), conspicuously swelling when wet; lobes poorly developed, irregularly branched, complexly ridged-plicate, isidiate; isidia marginal or laminal on ridges, granular and small (Fig. 7B); apothecia not seen.

Distribution and ecology. A widespread species, found in western Europe, North America and New Zealand (Galloway \& Jørgensen 1995). In Argentina, previously cited from northeast provinces (Calvelo \& Liberatore 2002). It occurs in shaded places, growing among mosses.

Selected specimen examined. ARGENTINA. Córdoba, El Hueco, 1865 m, 31 ${ }^{\circ} 58^{\prime} 12.8^{\prime \prime} \mathrm{S}, 64^{\circ} 56^{\prime} 54.6^{\prime \prime} \mathrm{W}, 19$ Oct. 2018, Rodriguez 4695 (CORD).
Leptogium cyanescens (Ach.) Körb., Systema lichenum Germaniae: 420. 1855.

(Fig. 7C)

For a detailed description see Galloway \& Jørgensen (1995).

Diagnostic characters. Thallus lobate, flat, loosely attached to substrate, pale to dark gray; lobes orbicular, irregularly folded, wavy, more or less ascending; upper surface slightly roughened, isidiate; isidia laminal or marginal, granular to cylindrical; lower surface glabrous; apothecia rare, circular, disc orange, margin thin.

Distribution and ecology. The species is widespread globally, especially in temperate and subtropical regions. In Argentina, it has been cited for Buenos Aires and Patagonia (Calvelo \& Liberatore 2002). Leptogium cyanescens grows on bark, rarely on stone and it is very common in Polylepis forests.

Selected specimen examined. ARGENTINA. Córdoba, El Hueco, 1865 m, 31 $58^{\prime} 12.8^{\prime \prime} \mathrm{S}, 64^{\circ} 56^{\prime} 54.6^{\prime \prime} \mathrm{W}, 19$ Oct. 2018, Rodriguez 4697 (CORD).

Leptogium laceroides B. de Lesd., Annales de Cryptogamie Exotique 6: 112. 1933.

(Fig. 7D)

For a detailed description see Galloway \& Jørgensen (1995).

Diagnostic characters. Thallus involute to flat, greyish-blue to brownish, loosely attached; lobes irregular, rather fragile, elongate-flabellate; margins usually ragged, crisped, and profusely isidiate; upper surface smooth, sometimes with whitish patches of short hairs; isidia terete, styliform, simple to coralloid, then lobulate-phyllidiate; lower surface minutely white pubescent; apothecia not seen.

Distribution and ecology. The species has been previously recorded for Patagonia (Calvelo \& Liberatore, 2002). It has been found on the bark of Polylepis.

Specimen examined. ARGENTINA. Córdoba, Parque Nacional Quebrada del Condorito, 2123 m, 31 ${ }^{\circ} 39^{\prime} 56.8^{\prime \prime} \mathrm{S}, 64^{\circ} 42^{\prime} 0,6^{\prime \prime} \mathrm{W}$, 14 Nov. 2018, Rodriguez 4698 (CORD).

Leptogium phyllocarpum (Pers.) Mont., Annales des Sciences Naturelles Botanique 10: 134. 1848. (Fig. 7E)

For a detailed description see Galloway \& Jørgensen (1995)

Diagnostic characters. Thallus subpulvinated, swelling with wet, loosely adnate, pale to dark gray; lobes oblong, anastomosing, with undulating margins; uppers surface with numerous prominent wrinkles or outgrowths; lower surface paler, also wrinkled, without hairs; apothecia submarginal to laminal, short pedicelate to sessile, with thick swelling margins.

Figure 6. New Parmeliaceae for Central Argentina. A-B - Hypotrachyna sinuosa (Rodriguez 4689); A - thallus; B - marginal soralia; C-D Hypotrachyna vexans (Rodriguez 4694); C - thallus; D - rhizines and lower surface and isidia on upper side; E-F - Parmelinopsis swinscowii (Rodriguez 4688); E - thallus; F - soralia subterminal; G-I - Usnea igniaria (Rodriguez \& Perazzo 4701); G - thallus; H - soralia; I - longitudinal section; J-K - Usnea subelegans (Rodriguez \& Perazzo 4700); J - thallus; $\mathrm{K}$ - longitudinal section. Scales: $\mathrm{A}=2.5 \mathrm{~cm} ; \mathrm{B}=0.5 \mathrm{~mm}$; $\mathrm{C}=2 \mathrm{~cm}$; $\mathrm{D}=6 \mathrm{~mm} ; \mathrm{E}=2 \mathrm{~cm} ; \mathrm{F}=3 \mathrm{~mm} ; \mathrm{G}=3 \mathrm{~cm} ; \mathrm{H}, \mathrm{I}=0.5 \mathrm{~mm} ; \mathrm{J}=5 \mathrm{~cm} ; \mathrm{K}=1 \mathrm{~mm}$. 

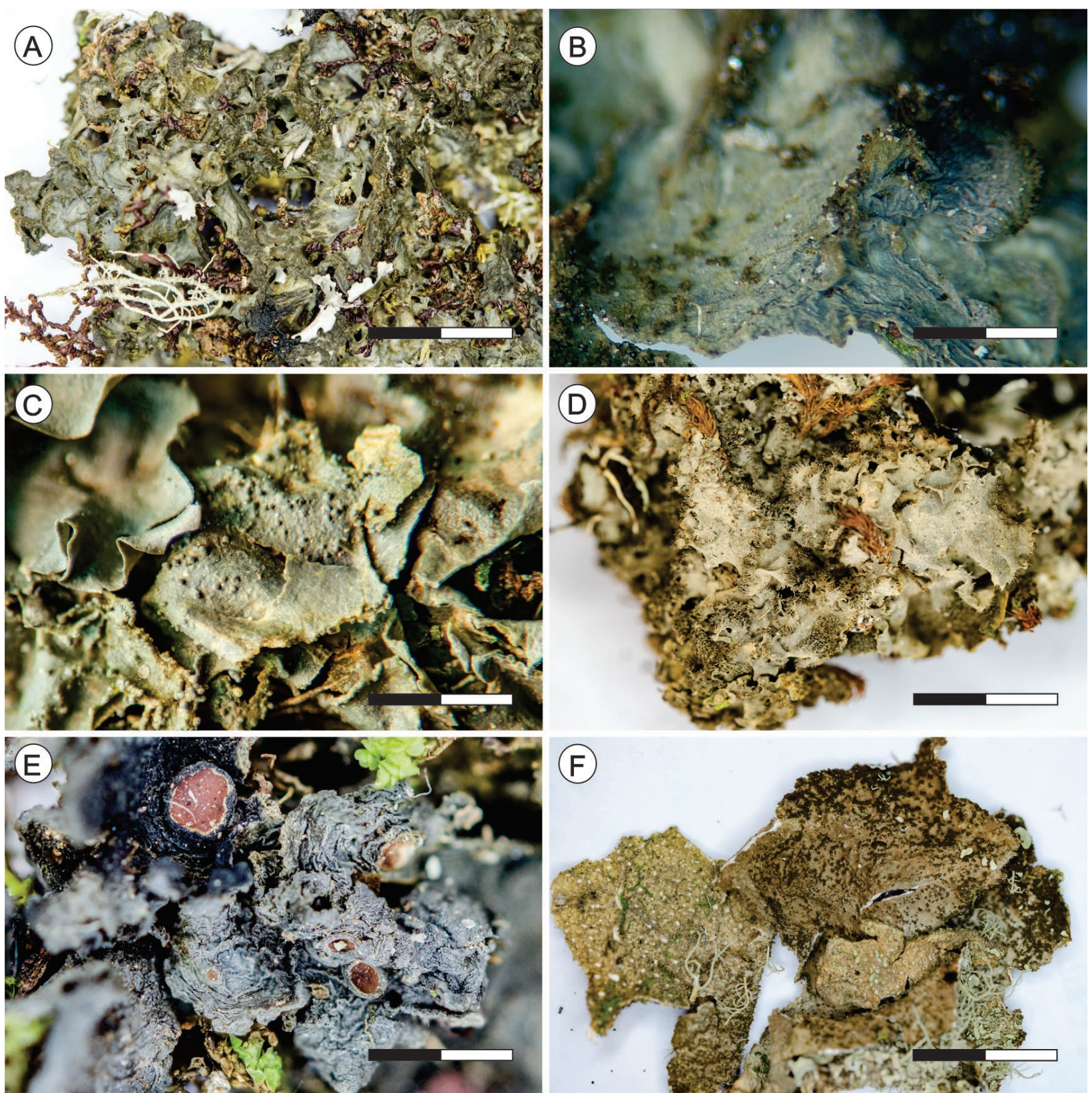

Figure 7. New Leptogium and Sticta records for Central Argentina. A-B - Leptogium brebissonii (Rodriguez 4695); A - general aspect; B detail of isidia; C - isidiate upper surface of Leptogium cyanescens (Rodriguez 4697); D - general aspect of Leptogium laceroides (Rodriguez 4698); E - general aspect of Leptogium phyllocarpon (Rodriguez 4696); F - general aspect of Sticta fuliginosa, left fragment showing cyphelae on underside (Rodriguez 4699). Scales. A, F = $1.5 \mathrm{~cm} ; \mathrm{B}, \mathrm{C}=0.5 \mathrm{~mm} ; \mathrm{D}=4 \mathrm{~mm} ; \mathrm{E}=5 \mathrm{~mm}$.

Distribution and ecology. It has been recorded in different regions of Argentina, probably a widely distributed species (Calvelo \& Liberatore 2002). This species is very common on Polylepis forest and it grows on bark and stone under the canopy.

Selected specimen examined. ARGENTINA. Córdoba, El Hueco, 1900 m, 31 ${ }^{\circ} 58^{\prime} 16.6^{\prime \prime} \mathrm{S}, 64^{\circ} 56^{\prime} 44,7^{\prime \prime} \mathrm{W}$, Rodriguez 4696 (CORD).

Parmelinopsis swinscowii (Hale) Elix \& Hale, Mycotaxon 29: 243.1987.

(Fig. 6E-F)

For a detailed description see Adler \& Calvelo (1993).

Diagnostic characters. Thallus foliose, grey, lobes subdichotomously branched, up to $3 \mathrm{~mm}$ wide (Fig. 6E); marginal cilia present up to $0.3 \mathrm{~mm}$ long; soralia subterminal to terminal, enlarging through the lamina (Fig. 6F); lower side black, rhizines simple, apothecia not seen.

Chemistry. Cortex $\mathrm{K}-$, medulla $\mathrm{K}+$ yellow to red, TLC: usnic, salazinic and lobaric (trace) acids.

Distribution and ecology. It is known from Africa, New Zealand and southern Argentina (Benatti 2012; Elvebakk et al. 2014). Parmelinopsis swinscowii has been described growing on stone or soil (Adler \& Calvelo 1993). However, it has been found on the bark in Polylepis forests.

Specimen examined. ARGENTINA. Córdoba. Los Gigantes, $2088 \mathrm{~m}, 31^{\circ} 24^{\prime} 17.0^{\prime \prime} \mathrm{S}, 64^{\circ} 48^{\prime} 29.4^{\prime \prime} \mathrm{W}$, on Polylepis australis, 22 Sep. 2018, Rodriguez 4688 (CORD). 
Sticta fuliginosa (Dicks.) Ach., Methodus Lichenum: 280. 1803.

(Fig. 7F)

For a detailed description see Galloway (1994).

Diagnostic characters. Thallus foliose, submonophilous, more or less orbicular, centrally attached to substratum, dark brown to ochraceous; lobes wide, upper surface irregular, covered by small globose to coralloid isidia; lower surface cream-whitish, covered by fine tomentum, with broad white cyphellae; apothecia very rare, not seen.

Distribution and ecology. The species is a cosmopolitan species. In Argentina, it is widely distributed (Rodriguez et al. 2016). It is usually found growing on bark or covered stones, in more or less exposed places.

Selected specimens examined. ARGENTINA. Córdoba, Parque Nacional Quebrada del Condorito, 2127 m, 31 ${ }^{\circ} 44^{\prime} 21.6^{\prime \prime} \mathrm{S}$, $64^{\circ} 48^{\prime} 03.4^{\prime \prime} \mathrm{W}$, on stone, 26 Dec. 2018, Rodriguez 4699 (CORD).

Usnea igniaria Motyka, Lichenum Generis Usnea Studium Monographicum. Pars Systematica 1: 108. 1936.

(Fig. 6G-I).

Diagnostic characters. Thallus shrubby, caespitous, up to $5 \mathrm{~cm}$ (Fig. 6G), yellowish-green; branches irregular; secondary branches not constricted at ramification point, terminal branches long and sinuous, segments cylindrical to slightly inflated and irregular to terete; fibrils scarce; papillae scarce to numerous, foveolae present, sometimes numerous; soralia originate from the cortex ad initio, irregular, plane to slightly excavate, isolated to partially confluent (Fig. $6 \mathrm{H}$ ); isidiomorphs rare; cortex moderately thin $4.6-7.1-10.3 \%$; medulla moderately thin $18.4-23.9-27.7 \%$ lax; central axis moderately thick 31.3-38.0-48.1\%, (Fig. 6I).

Chemistry. $\mathrm{K}-, \mathrm{C}-, \mathrm{KC}-$; TLC: usnic or usnic and psoromic acids.

Distribution and ecology. This species is common in Patagonia (Calvelo \& Liberatore 2002). However, it presents a wider distribution in Argentina (unpubl. data). It is corticolous and very common on shrubs or fences.

Selected specimen examined. ARGENTINA. Córdoba. Parque Nacional Quebrada del Condorito, seccional Condorito, $31^{\circ} 44^{\prime} 42.6^{\prime \prime} \mathrm{S}, 64^{\circ} 46^{\prime} 49.7^{\prime \prime} \mathrm{W}, 2052 \mathrm{~m}$, on shrubs, Oct. 2016, Rodriguez \& Perazzo 4701 (CORD).

Usnea subelegans (Vain.) Motyka, Annales de Cryptogamie Exotique 6: 122. 1933.

(Fig. 6J-K)

For a detailed description see Clerc (2007).

Diagnostic characters. Thallus shrubby to subpendulous, up to $8 \mathrm{~cm}$, yellowish-green (Fig. 6J); branches cylindrical, secondary branches not constricted to slightly constricted at ramification point, segments cylindrical and terete; fibrils dense, spinulous, up to $3 \mathrm{~mm}$ long.; apothecia frequent lateral; ascospores ellipsoid 6.4-9.6 $\times 3.2-6.4 \mu \mathrm{m}$; cortex thin and shiny 3.6-6.7-10.9\%; medulla moderately thin $10.3-24.1-31.1 \%$ lax to dense; central axis moderately thin, $11.5-38.3-68.8 \%$. (Fig. 6K).
Chemistry. $\mathrm{K}+$ yellow turning orange to red, $\mathrm{C}-$, $\mathrm{KC}-$, TLC: usnic, norstictic, galbinic and salazinic acids.

Distribution and ecology. Usnea subelegans is widespread from Mexico to Argentina (Gerlach et al. 2017). It is a very common apotheciate species widely distributed in Central and North Argentina (unpubl. data). It grows on Polylepis, several shrubs and fences.

Selected specimen examined. ARGENTINA. Córdoba. Parque Nacional Quebrada del Condorito, seccional Condorito, $31^{\circ} 44^{\prime} 42.6^{\prime \prime} \mathrm{S}, 64^{\circ} 46^{\prime} 49.7^{\prime \prime} \mathrm{W}, 2052 \mathrm{~m}$, on shrubs, Oct. 2016, Rodriguez \& Perazzo 4700 (CORD).

\section{Acknowledgments}

This work was supported by FONCyT - PICT 2016 projects for young researchers and SECyT - Universidad Nacional de Córdoba. We are grateful to the staff of Parque Nacional Quebrada del Condorito, especially to Fernanda Fabio and Fernando Morosini for the logistical support during several days of field work. We also thank Jackelyn M. Kembro for her review of the English. Finally, we thank the reviewers for useful comments. We dedicated this work to Philippe Clerc, the world-wide specialist on Usnea, who helped to understand this difficult genus allowing the discovery of its enormous diversity, especially in the Neotropics.

\section{References}

Adler, M. \& Calvelo, S. 1993. New reports of Parmeliaceae s.str. (lichenized Ascomycotina) from southwestern Argentina. Mycotaxon 46: $105-127$.

Adler, M. T. \& Calvelo, S. 2007. Ampliación de las distribuciones de especies de Parmeliaceae (Ascomycota liquenizados) en la República Argentina. Boletín de la Sociedad Argentina de Botánica 42: 1-11.

Ames-Martínez, F. N., Quispe Melgar, H. R., Zuñiga López, D. G., Segovia Salcedo, M. C. \& Kessler, M. 2019. Bosques de Polylepis: biodiversidad en la región central del Perú. Huancayo: Universidad Continental.

Bellis, L. M., Rivera, L., Politi, N., Martín, E., Perasso, M. L., Cornell, F. \& Renison D. 2009. Latitudinal patterns of bird richness, diversity and abundance in Polylepis australis mountain forest of Argentina. Bird Conservation International 19: 265-276.

Benatti, M. N. 2012. A worldwide key for the genus Parmelinopsis Elix \& Hale (Parmeliaceae; Lichenized Ascomycetes). Opuscula Philolichenum 11: 304-312.

Bungartz, F., Nordin, A. \& Grube, U. 2007. Buellia. In: Nash, III, T. H., Gries, G. \& Bungartz, F.: Lichen Flora of the Greater Sonoran Desert Region. Volume 3, pp. 113-179. Lichens Unlimited, Arizona State University, Tempe.

Cáceres, M. E. S. 2007. Corticolous crustose and microfoliose lichens of northeastern Brazil. Libri Botanici 22: 1-168.

Calvelo, S. \& Estrabou, C. 1997. The genus Cetrariastrum in southern South America and C. billingsii as a taxonomic synonym of C. americanum. Lichens 1: 11-17.

Calvelo, S. \& Liberatore, S. 2002. Catálogo de los líquenes de la Argentina. Kurtziana 29: 7-170.

Cingolani, A., Renison, D., Tecco, P., Gurvich, D. \& Cabido, M. 2008. Predicting cover types in a mountain range with long evolutionary grazing history: a GIS approach. Journal of Biogeography 35: 538-551.

Clerc, P. 1991. Usnea madeirensis Mot. (ascomycète lichénisé): un espèce méconnue de 1'Europe et de l'Amérique du Nord. Candollea 46: $427-438$. 
Clerc, P. 2006. Synopsis of Usnea (lichenized Ascomycetes) from the Azores with additional information on species in Macaronesia. The Lichenologist 38: 191-212.

Clerc P. 2007. Usnea. In: Nash III, T. H., Gries, C. \& Bungartz, F. (editors). Lichen Flora of the Greater Sonoran Desert Region. Volume 3. Lichens Unlimited: 302-335. Arizona State University (Tempe).

Clerc, P. 2011 Usnea. In: Thell, A. \& Moberg, R. (eds), Nordic Lichen Flora, Vol. 4, pp: 107-127. Uppsala: Nordic Lichen Society.

Colladon, L. 2002. Anuario pluviométrico 1999-2000. Cuenca del Río San Antonio. Sistema del Río Suquía-Provincia de Córdoba. Instituto Nacional del Agua y del Ambiente (INA) y Centro de Investigaciones de la Región Semiárida (CIRSA).

Cuyckens, G. A. E., Christie, D. A., Domic, A. I., Malizia, L. R. \& Renison, D. 2016. Climate change and the distribution and conservation of the world's highest elevation woodlands in the South American Altiplano. Global and Planetary Change 137: 79-87.

Elix, J. A. 2011. Cratiria. Australian Physciaceae (Lichenised Ascomycota). Australian Biological Resources Study, Canberra.

Elix, J. A., Edler, C. \& Mayrhofer, H. 2020. Two new corticolous species of Rinodina (Physciaceae, Ascomycota) from New Zealand. Australasian Lichenology 86: 95-101.

Elvebakk, A., Bjerke, J. W. \& Støvern, L. E. 2014. Parmelioid lichens (Parmeliaceae) in southernmost South America. Phytotaxa 173: $1-30$.

Fjeldså, J. \& Kessler, M. 2004. Conservación de la biodiversidad de los bosques de Polylepis de las tierras altas de Bolivia: una contribución al manejo sustentable en los Andes. Santa Cruz de la Sierra: FAN (DIVA technical report).

Fjeldså J. 2002. Polylepis forests vestiges of a vanishing ecosystem in the Andes. Ecotrópica. 8: 111-23.

Galloway, D. 1994, Studies on the lichen genus Sticta (Schreber) Ach.: I. Southern South American species. The Lichenologist 26: 223-282.

Galloway D. \& Jørgensen P. M., 1995. The lichen genus Leptogium (Collemataceae) in southern Chile, South America. In: Daniels, F.; Schulz, M. \& Peine, J. (eds), Contributions to Lichenology in honour of G. Follmann, pp. 227-247. Geobotanical and Phytotaxonomical Study Group, Botanical Institute Cologne, University of Cologne.

Gerlach, A. C. L., Clerc, P \& Borges da Silveira, R. M. 2017. Taxonomy of the corticolous, shrubby, esorediate, neotropical species of Usnea Adans. (Parmeliaceae) with an emphasis on southern Brazil. The Lichenologist 49: 199-238.

Giralt, M. \& Mayrhofer, H. 1991. Rinodina boleana spec. nova, a new lichen species from north-eastern Spain. Mycotaxon 40: 435-439.

Giralt, M., Kalb, K. \& Mayrhofer, H. 2009. Rinodina brasiliensis, a new corticolous isidiate species, and closely related taxa. The Lichenologist 41: 179-187.

IUCN. The IUCN red list of Theatrened species. Version 2020-1 [Internet]. 2020 [cited 2020 May 3]. https://www.iucnredlist.org

Halonen, P., Clerc, P., Goward, T., Brodo, I. M. \& Wulff, K. 1998 Synopsis of the genus Usnea (lichenized Ascomycetes) in British Columbia, Canada. The Bryologist 101: 36-60.

Harden, C. P., Hartsig, J., Farley, K. A., Lee, J., \& Bremer, L. L. 2013. Effects of land-use change on water in Andean Páramo grassland soils. Annals of the Association of American Geographers 103: 375-384.

Herrera-Campos, M. A., Nash III, T. H. \& Garcia, A. Z. 2001 Preliminary study of the Usnea fragilescens aggregate in Mexico. The Bryologist 104: 235-259.

Jørgensen, P. M., 2001. The present status of the names applicable to species and intraspecific taxa of Erioderma (lichenized ascomycetes) included in Zalhbruckner's Catalogus. Taxon 50: 524-541

Jørgensen, P. M. \& Arvidsson, L., 2002. The lichen genus Erioderma (Pannariaceae) in Ecuador and neighbouring countries. Nordic Journal of Botany 22: 87-114.
Kitaura, M. J. 2012 Estudos taxonômicos de Leptogium (Ach.) S.F. Gray (Collemataceae, fungos liquenizados). $\mathrm{PhD}$ thesis, Universidade Estadual Paulista, Botucatu. http://hdl.handle.net/11449/104010

Lamb, I. M. 1958. La vegetación liquénica de los Parques Nacionales Patagónicos. Anales de Parques Nacionales 7: 1-188.

Malme, G. O. 1902. Die Flechten der ersten Regnell‘schen Expedition. II. Die Gattung Rinodina (Ach.) Stiz. Bihang till Kongl. Svenska Vetenskaps-Akademiens Handlingar 28: 1-53.

Marcano, V.; Morales Méndez, A., Sipman, H., \& Calderon, L. 1996. A first checklist of the lichen-forming fungi of the Venezuelan Andes. Tropical Bryology 12: 193-235.

Mayrhofer, H., Kantvilas, G. \& Ropin, K. 1999. The corticolous species of the lichen genus Rinodina (Physciaceae) in temperate Australia. Muelleria 12: 169-194.

Mayrhofer, H., Sheard, J. W., Grassler, M. C. \& Elix, J. A. 2001 Rinodina intermedia (Physciaceae, lichenized Ascomycetes): a well-characterized species with submuriform ascospores. The Bryologist 104: 456-463.

Mayrhofer, H., Lambauer, M. \& Edler, C. 2007. Rinodina (Ach.) Gray, 1821. In: Galloway, D. J. Flora of New Zealand: Lichens, including lichen-forming and lichenicolous fungi. Rev. 2nd ed., pp. 15631590. Lincoln, NZ: Manaaki Whenua Press, Landcare Research.

Mayrhofer, H., Obermayer, W. \& Wetschnig, W. 2014. Corticolous species of the genus Rinodina (lichenized Ascomycetes, Physciaceae) in southern Africa. Herzogia 27: 1-12.

Moberg, R. 1993. The lichen genus Phaeophyscia in South America with special reference to Andean species. Opera Botanica 121: 281-284.

Moberg, R. 1995. The lichen genus Phaeophyscia in China and Russian Far East. Nordic Journal of Botany 15: 319-335.

Müller, J. 1893. Lichenes exotici II. Hedwigia 32: 120-136.

Nordin, A. 1999. Buellia species with pluriseptate spores: new and unrecorded species in North America. The Bryologist 102: 249-264.

Nordin, A. 2001, Buellia species with pluriseptatate spores and the Physciaceae (Lecanorales, Ascomycotina), Symbolae Botanicae Upsalienses 33: 1-126.

Orange, A., James, P. W., \& White, F. J. 2001. Microchemical Methods for the Identification of Lichens. British Lichen Society. $101 \mathrm{pp}$.

Osorio, H. \& Ferraro, L. 1975. Contribution to the lichen flora of Argentina VII. New and noteworthy records from the Province of Corrientes. Comunicaciones Botánicas del Museo de Historia Natural de Montevideo 57: 1-4.

Passo, A., Díaz Dominguez, R. \& Rodriguez, J. M. 2020. Nuevos registros y actualización del conocimiento sobre el género Pannaria en la Argentina. Boletín de la Sociedad Argentina de Botánica 55: 339-357.

Perazzo, A. \& Rodriguez, J. M. 2019. Impacto del fuego sobre la vegetación no vascular del suelo: un estudio de caso en los bosques de Polylepis australis (Rosaceae) del centro de Argentina. Lilloa 56: $67-80$.

Pulido Herrera, K. \& Ramos Montaño, C. 2016. Efecto de borde en la distribución de líquenes y el contenido de clorofilas en fragmentos de Polylepis quadrijuga (Rosaceae) en el páramo de La Rusia (Boyacá-Colombia). Revista de Biología Tropical 64: 1683-1697.

Quispe-Melgar, H. R., Sevillano-Ríos, C. S., Navarro Romo, W. C., Ames-Martínez, F. N., Camel V. et al. 2020. The Central Andes of Peru: a key area for the conservation of Polylepis forest biodiversity. Journal of Ornithology 161: 217-28.

Renison, D, Griet A. E., Cuyckens, Pacheco, S., Guzmán, G., Grau, H., Marcora, P., Robledo, G-, Cingolani, A., Dominguez, J., Landi, M, Bellis, L. \& Hensen, I. 2013. Distribución y estado de conservación de las poblaciones de árboles y arbustos del género Polylepis (Rosaceae) en las montañas de Argentina. Ecología Austral 23: 27-36.

Renison, D., Cingolani, A. \& Suárez, R. 2002. Efectos del fuego sobre un bosquecillo de Polylepis australis (Rosaceae) en las montañas 
de Córdoba, Argentina. Revista Chilena de Historia Natural 75: 719-727.

Renison, D., Morales, L., Cuyckens, E, Sevillano, C. S., Cabrera Amaya, D. M. 2018. Ecología y conservación de los bosques y arbustales de Polylepis: ¿Qué sabemos y qué ignoramos? Ecología Austral 28: $163-174$.

Robledo, G., Urcelay, C. \& Rajchenberg, M. 2003. New species causing decay on living Polylepis australis in Córdoba, central Argentina. Mycologia 95: 347-353.

Robledo, G. \& Renison, D. 2010. Wood-decaying polypores in the mountains of central Argentina in relation to Polylepis forest structure and altitude. Fungal Ecology 3: 178-184.

Rodriguez, J. M., Estrabou, C., Truong, C. \& Clerc, P. 2011. The saxicolous species of the genus Usnea subgenus Usnea (Parmeliaceae) in Argentina. The Bryologist 114: 504-525.

Rodriguez, J. M., Hernandez, J. M., Filippini, E., Cañas, M. \& Estrabou, C. 2016. Nuevas citas de macrolíquenes para Argentina y ampliaciones de distribución en el centro del país. Boletín de la Sociedad Argentina de Botánica 51: 405-417.

Rodriguez, J. M., Renison, D., Filippini, E. \& Estrabou, C. 2017. Climate change in the mountains: Insights from a study of saxicolous lichen communities in relation to altitude and microsite. Biodiversity and Conservation 26: 1199-1215.

Rodriguez, J. M. \& Filippini, E. 2020. In press. Three new synonyms of lichens based on Köfaragó-Gyelnik type collection. Acta Botanica Hungarica 62: 411-416.

Segovia, M., Domic, A., Boza, T., Kessler, M. 2018. Situación taxonómica de las especies del genero Polylepis Implicancias para los estudios ecológicos, la conservación y la restauración de sus bosques. Ecología Austral 28: 188-201.
Sheard, J. W. 2010. The Lichen Genus Rinodina (Lecanoromycetidae, Physciaceae) in North America, North of Mexico. National Research Council of Canada, NRC Research Press, Ottawa.

Sierk, H. A. 1964. The genus Leptogium in North America north of Mexico. The Bryologist 67: 245-317.

Sipman, H. J. M., Hekking, W. \& Aguirre, C. J. 2008. Checklist of Lichenized and Lichenicolous Fungi from Colombia. Biblioteca José Jerónimo Triana No. 20. Instituto de Ciencias Naturales, Facultad de Ciencias, Universidad Nacional de Colombia, Bogotá.

Stizenberger, E. 1890. Lichenaea Africana. Fasc. Prior. Bericht über die Thätigkeit der St. Gallischen Naturwissenschaftlichen Gesellschaft während des Vereinsjahres 1888-89: 105-249.

Spielmann, A. A. 2006. Checklist of lichens and lichenicolous fungi of Rio Grande do Sul (Brazil). Caderno de Pesquisa Série Biologia 18: 7-125.

Sylvester, S. P., Heitkamp, F., Sylvester, M. D. P. V., Jungkunst, H. F., Sipman, H. J. M., et al. 2017. Relict high-Andean ecosystems challenge our concepts of naturalness and human impact. Scientific Reports 7: 3334.

Tarifa, T. \& Yensen, E. 2001. Mammals of Bolivian Polylepis woodlands. Revista Boliviana de Ecología 9: 29-44.

Tibell, L. 1996. Caliciales. Flora Neotropica, 69 New York Botanical Garden, New York.

Truong, C., Bungartz, F. \& Clerc, P. 2011 The lichen genus Usnea (Parmeliaceae) in the tropical Andes and the Galapagos: species with a red-orange cortical or subcortical pigmentation. The Bryologist 114: 477-503.

Truong, C. \& Clerc, P. 2016. New species and new records in the genus Usnea (Parmeliaceae, lichenized Ascomycota) from tropical South America. The Lichenologist 48: 71-93. 